\title{
Analisis Pentingnya Pembangunan Pendidikan Karakter Siswa Dalam Mengembangkan Kualitas Sumber Daya Manusia di SMP Muhammadiyah Surakarta
}

\author{
Ika widiastuti ${ }^{1}{ }$ Julhidayat Muhsam $^{2}$, Pandu Adi Cakranegara ${ }^{3}$ \\ ${ }^{1}$ Universitas Krisnadwipayana, ${ }^{2}$ Universitas Muhammadiyah Kupang, \\ ${ }^{3}$ Universitas Presiden \\ iwidiastuti86@gmail.com, julhidayat.1.muhsam@gmail.com, \\ pandu.cakranegara@president.ac.id
}

Received: 12 Januari 2021; Revised: 26 Februari 2021; Accepted: 28 April 2021

DOI: http://dx.doi.org/10.37905/aksara.7.2.255-262.2021

\begin{abstract}
ABSTRAK
Pembangunan pendidikan karakter sangat penting dilaksanakankarena siswa tidak hanya dididik dari segi kecerdasan intelektual saja namun dididik pula dari segi karakter atau perilaku positif siswa. Namun pada kenyataannya banyak perilaku negative yang dilaksanakan oleh siswa.Hal ini menjadi tugas pokok pemerintah, pengajar, orang tua dan masyarakat untuk berperan dalam memajukan pembangunan pendidikan karakter guna mewujudkanSDM yang bermutu. Adapun tujuan penelitian adalah dapat mengetahui kendala dalam membentuk perilaku positif siswa di SMP Muhammadiyah Surakarta.Metode penelitian yaitu kualitatif yang bertujuan untuk melakukan pengamatan terhadap perilaku orang.Hasil penelitian yaitu pelaksanaan pendidikan moral dapat mempengaruhi perilaku siswa. Diharapkan dapat merubah dan membentukperilaku siswa menjadi lebih baik. Diperlukan adanya kerjasama dan dukungan berbagai pihak supaya implementasi pendidikan karakter dapat berjalan dengan efektif.
\end{abstract}

Kata Kunci : pembangunan, pendidikan karakter, sumber daya manusia

\section{ABSTRACT}

The development of character education is very important because students are not only educated in terms of their intellectual intelligence but also in terms of character or positive student behavior. But in reality there are still many negative behaviors carried out by students. This is the main task of the government, teachers, parents and society to play a role in advancing the development of character education in order to realize quality human resources. The purpose of this research is to be able to identify barriers in shaping positive behavior of students of SMP Muhammadiyah Surakarta. The research method is qualitative which aims to observe people's behavior. The result of this research is that the application of moral education can influence student behavior. It is hoped that it can change and shape student behavior for the better. It needs cooperation and support from various parties so that the implementation of character education can run effectively.

Keywords: development, character education, human resources

\section{PENDAHULUAN}

Pendidikan dan pembangunan karakter sangat penting untuk dilaksanakan karena untuk mengembangkan sumber daya manusia (SDM) yang berkualitas. Namun dalam kenyataannya banyak pelanggaran yang dilakukan oleh siswa selama 
berkecimpung dalam dunia pendidikan dan setelah lulus belajar di sekolah/universitas misalnyamelakukan pembunuhan, narkoba, perampokan, korupsi, tawuran, dan seks bebas (Kesuma, 2011:4). Sebaiknya pendidikan moral tidak hanya diterapkan dalam pelajaran agama saja tetapi di semua mata pelajaran. Orang tua dan guru bertanggungjawabuntuk menunjukkan karakter positif sehingga implementasi pendidikan karakter dapat berjalan dengan efektif sehingga dapat membentuk SDM yang berkualitas yaitu memiliki kecerdasan intelektual yang tinggidan berakhlak mulia.Melalui pendidikan diharapkan dapat menanamkan perilaku positif kepada para peserta didik, serta dapat mengubah sifat atau perilaku siswa menjadi lebih baik (Gunawan, 2012:4). Berdasarkan data dari KPAI tahun 2018 terdapat kasus perilaku negatif siswa diantaranya narkoba 17,8\%, mencuri $23,9 \%$, asusila $13,2 \%$. Hal ini membuktikan bahwa semakin maraknya perilaku negatifsiswa, sekolah dan universitas lebih banyak condong menilai dari segi kecerdasan intelektual saja tanpa memperhatikan perilaku siswa sehingga akan menghasilkan SDM yang tidak berkualitas.

Dibentuknya pendidikan karakter diharapkan masyarakat mempunyai kesadaran dalam mematuhi peraturan dan berperilaku yang baik sehingga mampu mewujudkan karakter warga negara yang demokratis dan harmonis.Pembangunan moral dapat diterapkan di bangku sekolah dan perguruan tinggi sehingga dapat mewujudkan SDM yang cerdas,sopan santun, bermartabat, serta dapat bersaing dengan negara lain (Amri, 2011 : 50). Apabila siswa memiliki karakter yang kuat maka akan menghadapi segala hambatan dan rintangan yang menghadang dan pantang menyerah. Pendidikan karakter dapat menciptakan mental pemenang untuk generasi yang akan datang (Asmani, $2011:$ 19-20). Guru dan orang tua siswaharus dapat mendidikbagaimana berperilaku yang baik. Salah satu contoh sekolah formal yang menanamkan perilaku moral siswa yaitu SMP Muhammadiyah Surakarta yang memiliki visi membentuk karakter siswa berakhlak yang mulia, professional, mandiri dan berprestasi. Berdasarkan hasil pengamatan bahwa di lingkungan SMP Muhammadiyah Surakarta telah menanamkan karakter yang baik namun pada realitanya terdapat siswa yang melakukan pelanggaran. Misalnya siswa belum dapat menghargai dan menghormati guru serta siswa yang lain, berperilaku tidak sopan dan tidak mentaati peraturan sekolah. Hal inilah yang menjadi kepedulian SMP Muhammadiyah Surakarta untuk melakukan pembinaan karakter siswa. Rumusan masalah yaitu apakah kendala dalam membangun perilaku positif siswa sehingga dapat mewujudkan SDM yang bermutu tinggi. Tujuan penelitian yaitu memahami konsep, teori mengenai pendidikan moral dan SDM, dapat mengetahui kendala apa saja dalam membangun pendidikan karakter siswa, dan untuk mengetahui sikap yang diperlukan dalam membentuk kepribadian siswa menjadi pribadi yang lebih baik guna meningkatkan SDM yang berkualitas.

\section{METODE PENELITIAN}

Subjek penelitian yaitu siswa SMP Muhammadiyah Surakarta sedangkan objek penelitiannya adalah pembangunan pendidikan karakter pada siswa SMP Muhammadiyah Surakarta. Teknik pengumpulan yaitu observasi, wawancara, dan dokumentasi (Moleong, 2012). 
Metode jenis penelitian ini adalah penelitian kualitatif. Bogdan dan Taylor (1992: 21-22) menjelaskan bahwa penelitian kualitatif adalah salah satu prosedur penelitian yang menghasilkan data deskriptif berupa lisan atau tertulis dan perilaku orang-orang yang diamati. Penelitian kualitatif digunakan untuk melakukan pengamatan terhadap keadaan objek, peneliti sebagai instrumen kunci (Sugiyono, 2005). Menurut Moleong (2005: 6), penelitian kualitatif bertujuan melakukan pengamatan pada subjek penelitian contohnya sifat seseorang kemudian mendeskripsikannya melalui berbagai kata dan bahasa sedangkan menurut Saryono (2010), penelitian kualitatif bertujuan untuk melakukanpenyelidikan, penemuan, melalui pendekatan kuantitatif.

\section{PEMBAHASAN}

\section{Pendidikan Karakter}

Kertajaya (2010:13) karakter adalah sifat individu yang dapat memotivasi seseorang untuk berperilaku, bersikap dan respon terhadap sesuatu sedangkan Koesoema (2010:3) mendefinisikan pendidikan karakter merupakan manusia menghayati kebebasan dan keterbatasan dirinya sehingga perbuatannya harus dapat dipertanggungjawabkan. Rahardjo (2010:16) pendidikan karakter adalah proses pembangunan dan perkembangan yang berkaitan dengan akhlak sehingga peserta didik dapat hidup mandiri, melakukan perbuatan kebenaran yang dapat dipertanggungjawabkan, dan pada akhirnya membentuk generasi yang berkualitas.

Prasetyo dan Rivasintha (2013:30) pendidikan karakter bertujuan untuk menerapkan akhlak yang baik melalui ilmu pengetahuan, adanya keinginanserta perbuatan peserta didik supaya dapat melakukan nilai tersebut.

Tujuan pendidikan karakter adalah :

1. Dapat mengetahui berbagai karakter.

2. Dapat menjelaskan berbagai karakter.

3. Dapat mengetahui contoh perilaku karakter yang baik.

4. Dapat menjaga karakter yang baik.

\section{Kualitas Sumber Daya Manusia}

Soekidjo Notoadmodjo (2003:3) mengatakan kualitas SDM terdiri dari kualitas fisik dan non fisik yang berkaitan dengan kemampuan berfikir,memiliki keahlian/skill dan kemampuan dalam bekerja.

Danim (1996:44) berpendapat bahwakualitas SDM adalah SDM yang memiliki mutu dalam hal kualitas jasmani, kecerdasan dan mental.

Ruky (2006:16)sifat SDM bermutu ialah :

1. Bertanggung jawabdalam menyelesaikan tugas sesuai dengan kewenangan yang diberikan kepadanya.

2. Mempunyai pengetahuan yang memadai.

3. Dapat menyelesaikan pekerjaan dengan baik dan mempunyai skill.

4. Melakukan sesuatu hal/pekerjaan yang berguna bagi sesama, menghasilkan suatu karya, bekerja sama serta loyal.

Menurut Sumardjan (2000:21) sifat SDM yang bermutu :

1. Tidak putus asa pada nasib.

2. Membangun kembali kodratnya.

3. Siap menghadapi perubahan sosial budaya. 
4. Bersedia, mampu bekerja sama, serta menghormati hak dan kewajiban orang lain.

5. Memiliki moral yang tinggi, antara lain jujur, merespon terhadap hak orang lain, dan menepati janji.

SDM merupakan mengeluarkan seluruh kemampuan seseorang dengan maksimal yang ada pada pribadi orang tersebut dan mengolah SDA sekitar untuk mencapai kemakmuran.Dengan demikian, pendidikan karakter dapat tercapai apabila peserta didik memiliki kecerdasan dan perilaku yang baik pula sehingga mewujudkan SDM yang berkualitas/bermutu. Hal ini dapat diimplementasikan melalui pendidikan di universitas dan sekolah. Moralitasakan menjadi luntur akibat adanya tren dunia modern sehingga adat istiadat, peraturan serta norma sudah tidak lagi ditaati. Perilaku positif menjadi memudar karena terpengaruh budaya barat. Semangat kreativitas, produktivitas, dan inovatif berubah menjadi gaya hidup yang mengutamakan kesenangan dan berperilaku boros. SDM yang bermutu ditentukan oleh faktorkesehatan, kecerdasan, dan kepribadian. (1) Kesehatan maksudnya senantiasa bugar, tidak mudah sakit dan selalu fit, (2) Kecerdasan maksudnya memiliki kemampuan berpikir untuk menganalisis sesuatu hal, (3) Kepribadian maksudnya mempunyai sifat yang terpuji. Diperlukan revolusi mental untuk mengatasi perilaku negatifsiswa. Perilaku negative siswa kan berdampak pada perilaku siswa sendiri, masyarakat, bangsa dan negara. Apabila perilaku negative terus dibiarkan maka produktivitas dan daya saing bangsa akan lemah dan tidak bermartabat.

Berikut ini merupakan prioritas pembangunan SDM yaitu :

1. Memberikan keamanan bagi seluruh rakayat Indonesia.

2. Menciptakan good government, bebas KKN, dan demokratis.

3. Membangun desa di Indonesia tanpa adanya diskriminasi.

4. Mewujudkan negara yang bermartabat.

5. Mengembangkan SDMbermutu tinggi.

6. Meningkatkan mutu SDM dengan dilaksanakannya diklat dan menumbuhkan perekonomian rakyat.

7. Diperlukan kompetensi yang sehat dan melakukan sesuatu hal yang bermanfaat bagi orang lain.

8. Memperbaiki karakter bangsa melalui pendidikan kewarganegaraan dan agama.

9. Melakukan perubahan sosial supaya pendidikan Indonesia lebih maju dan semakin baik.

Pada saat ini yang dibutuhkan oleh siswa di Indonesia yaitu revolusi mental.

Di mana revolusi mentalini terdiri atas :

1. Integritas.

2. Kerja Keras.

3. Gotong royong.

Seluruh stakeholder harus memproduksi lulusan yang memiliki kecerdasan intelektual dan karakter positif. Namun faktanya banyak perilaku siswa yang melakukan penyimpangan dan banyak pula yang meraih juara pada tingkat nasional maupun internasional. Bukti pendidikan nasional Indonesia yang belum dapat berjalan dengan maksimal yaitudominan pada kecerdasan daripada karakter. Sehingga akan menyebabkan menjadi manusia yang tidak memiliki rasa saling 
menghargai dan menghormati, rasa cinta, dan budi pekerti. Terdapat tiga bidang ilmu yang dikuasaiyaitu kognitif, afektif, serta psikomotorik. (1) Kognitif terdiri dari iptek, (2) afektif terdiri karakter, sedangkan (3) psikomotorik terdiri dari keterampilan yang bersifat procedural. Diharapkan terdapat keseimbangan ketiga ilmu yang harus diperoleh siswa. Tetapi fakta di lapangan menunjukkan bahwa siswa lebih cenderung kepada ranah kognitif sedangkan ranah yang lainnya diabaikan sehingga akan menghasilkan siswa yang belum bisa bekerjasama dengan tim, egois. Hal inilah yang menjadi hambatan mengapa pembangunan pendidikan karakter belum dapat berjalan maksimal sebagaimana yang diharapkan.Sebaiknya seluruh stakeholder bekerja sama mendukung pembangunan pendidikan karakter, dengan cara menerapkan di setiap pembelajaran dan dalam kehidupan sehari-hari sehingga tujuan pendidikan nasional yaitu mencerdaskan, membina karakter siswa yang berahklak mulia dapat tercapai. Pada kenyataannya proses pendidikan karakter belum dapat berjalan dengan maksimal karena lebih menekankan pada prestasi keberhasilan siswa sebagai ukuran pertama daripada karakter perilaku siswa. Sehingga banyak siswa yang melakukan perilaku menyimpang, contohnya siswa berkata yang kurang sopan kepada gurunyadan setelah tamat sekolah melakukan hal yang negatif contohnya : korupsi. Kasus tersebut menunjukkan bahwa telah menurunnya moral dan karakter anak bangsa. Sebaiknya siswa dapat menerapkan nilai Pancasila, UUD 1945, dan mematuhi peraturan yang berlaku dalam kehidupan sehari-hari sehingga setelah siswa tamat sekolah kemudian terjun ke lapisan masyarakat dapat memiliki karakter yang baik.

Pentingnya pendidikan harus dapat dilaksanakan sejak dini sehinga dapat mewujudkan sikap warga negara Indonesia yang memiliki karakter yang baik. Terdapat perilaku yang harus dapat diterapkan oleh siswa yaitu :

\section{Religius}

Religius menunjukkan bahwa kita selalu mentaati dan melaksanakan ajaran agama, bersikap toleransi kepada orang yang berbeda agama sehingga akan mewujudkan hidup damai dan rukun.

\section{Jujur}

Dengan diterapkannya sikap jujur dalam kehidupan sehari-hari, maka dapat memperoleh kepercayaan.

\section{Toleransi}

Dengan adanya sikap toleransi maka kita akan hidup rukun dan damai. Contoh dari sikap toleransi yaitu menghargai perbedaan pendapat orang lain, tidak memaksakan pendapat sendiri.

\section{Disiplin}

Sikap disiplin sangat penting untuk dilaksanakan. Kita dituntut senantiasa patuh dan tertib pada peraturan yang telah ditetapkan.

\section{Kerja Keras}

Dengan adanya sikap kerja keras maka kita dapat menyelesaikan tugas dan pekerjaan hal apapun serta dapat mengatasi segala hambatan.

\section{Kreatif}

Dengan adanya sikap kreatif maka kita akan selalu senantiasa berproduktif dan berinovatif dalam mengerjakan tugas serta menghasilkan ide-ide baru sehingga dapat bersaing baik nasional maupun internasional. 


\section{Mandiri}

Mandiri yang dimaksud adalah melakukan pekerjaan atau tugas seorang diri tanpa adanya bantuan orang lain untuk menyelesaikan tugasnya.

\section{Demokratis}

Dengan adanya sikap demokratis maka kita dapat berfikir, berperilaku dapat senantiasa mampu menyeimbangkan hak dan kewajiban.

\section{Keingintahuan yang tinggi}

Dengan adanya keingintahuan yang tinggi maka timbul keinginan supaya rajin belajar, menggali informasi ilmu pengetahuan yang baik dalam bidang apapun.

\section{Semangat Kebangsaan}

Misalnya dapat meraih prestasi dalam bidang apapun sehingga dapat mengharumkan nama baik negara Indonesia.

\section{Cinta Tanah Air}

Contohnya mematuhi tata tertib yang telah ditetapkan, menggunakan produk dalam negeri.

\section{Menghargai Prestasi}

Dapat dilakukan dengan cara memberikan pujian atas prestasi yang telah diraihnya. Dengan adanya sikap menghargai terhadap prestasi orang lain maka kita menghormati dan mengakui keberhasilan orang tersebut.

\section{Bersahabat/Komunikatif}

Kita harus menanamkan sikap selalu bersahabat dalam pertemanan, senantiasa ramah dan sopanserta selalu berinteraksi dengan orang lain.

\section{Cinta Damai}

Dengan adanya sikap cinta damai terhadap sesama maka mendorong kita senantiasa bertoleransi.

\section{Gemar Membaca}

Dengan adanya gemar membaca, maka warga negara Indonesia akan semakin pintar dan dapat terbuka terhadap ilmu pengetahuan yang baik.

\section{Peduli Lingkungan}

Dapat diterapkan melalui senantiasa menjaga kebersihan serta tidak merusak lingkungan.

\section{Peduli Sosial}

Sikap kepedulian sosial terhadap sesama sangat penting dilakukan oleh seluruh warga negara Indonesia. Contohnya dengan memberikan bantuan kepada orang lain.

\section{Tanggung Jawab}

Maksudnya melaksanakan hak dan kewajiban sesuai dengan kewenangannya.

Pendidikan karakter dapat diterapkan dengan menanamkan nilai Pancasila, religious, mandiri, integritas, gotong royong dan nasionalis. Kurang tegasnya dari penegak hukum merupakan akibat dari banyaknya perilaku negative siswa. Penguatan pendidikan karakter yaitu dengan cara menerapkan nilai Pancasila.Jadi sudah sangatlah jelas bahwa fungsi dari pendidikan yaitu bukan hanya mencerdaskan kehidupan bangsa saja namun mampu membentuk karakter yang mulia. 


\section{PENUTUP}

Pada realitanya, banyak sekali permasalahan siswa maka diperlukan adanya pendidikan untuk pembangunan dan perkembangan karakter siswa. Pentingnya pendidikan karakter harus ditanamkan sejak dini. Diharapkan dengan diterapkannya pendidikan karakter dapat merubah perilaku anak menjadi baik. Diperlukan peran, dukungan dan tanggung jawab keluarga, guru, masyarakat dan pemerintah dalam menerapkan pendidikan karakter yang baik.

\section{DAFTAR PUSTAKA}

A., Doni Koesoema. (2010). Pendidikan Karakter; Strategi Mendidik Anak di Zaman Global.Jakarta: Grasindo.

Achmad, S.Ruky. (2006). Sistem Manajemen Kinerja. Jakarta : PT Bumi Aksara.

Amri, Sofan dkk. (2011). Implementasi Pendidikan Karakter Dalam Pembelajaran. Jakarta: Prestasi Pustakaraya.

Asmani, Jamal Ma'mur. (2011). Buku Panduan Internalisasi Pendidikan Karakter di Sekolah. Jogjakarta: Diva Press.

Bogdan \& Taylor. (1992). Pengantar Metode Penelitian Kualitatif; suatu pendekatan fenomenologis terhadap ilmu ihnu sosial. Surabaya: Usaha Nasional.

Danim, Sudarwan. (1996). Transformasi Sumber Daya Manusia. Jakarta: Bumi Aksara.

Gunawan, H. (2012). Pendidikan Karakter (Konsep dan Implementasi). Bandung:Alfabeta.

Kertajaya, Hermawan. (2010). Grow with Character: The Model Marketing. Jakarta: PT Gramedia Pustaka Utama.

Kesuma, Dharma, dkk. (2011). Pendidikan Karakter : Kajian Teori dan Praktik di Sekolah. Bandung:PT Remaja Rosdakarya

Moleong, Lexy J. (2012). Metodologi Penelitian Kualitatif. Bandung: PT Remaja Rosdakarya. , (2005). Metodologi Penelitian Kualitatif. Bandung: PT Remaja Rosdakarya.

Notoatmodjo, Soekidjo. (2003). Pengembangan Sumber Daya Manusia. Jakarta: PT. Rineka Cipta.

Rahardjo. (2010). Pendidikan Karakter Sebagai Upaya Menciptakan Akhlak Mulia. Jurnal Pendidikan dan Kebudayaan, 16 (3).

Saryono. (2010). Metode Penelitian Kualitatif. Bandung: PT Alfabeta.

Sedarmayanti. (2000). Restukturisasi dan Pemberdayaan Organisasi untuk Menghadapi Dinamika Perubahan Lingkungan. Bandung: Masdar Maju.

Sugiyono. (2005). Memahami Penelitian Kualitatif. Bandung: CV. Alfabeta 
P-ISSN $\underline{2407-8018}$ E-ISSN $\underline{2721-7310}$ DOI prefix $\underline{10.37905}$

Volume 07 (02) Mei 2021

http://ejurnal.pps.ungac.id/index.php/Aksara 